\title{
New Service Development in the Context of Organization Strategy
}

\author{
Povilas Švogžlys \\ Vilnius Gediminas Technical University, Saulètekio al. 11, LT-10223, Vilnius, Lithuania \\ E-mail of the corresponding author: povilas.svogzlys@gmail.com
}

\begin{abstract}
In order to stand out in a competitive environment, business entities pay lots of attention and resources for shaping a new business strategy or developing an existing one. A well-designed and consistent implemented strategy allows the business entity to achieve new goals, assess progress, distribute the workload evenly and develop an efficient decision-making system. This research is becoming extremely relevant in today's context when more and more service organizations are growing and constantly offering new job positions. In this case one of the potential business strategies that business entities could take is the development of new services. The concept of strategy by itself is analyzed in accordance with the researches of different authors. The added value of the new services development process for the business entity is evaluated from a strategic point of view. Based on the analysis, the guidelines for further research were formulated. The methods of comparative analysis and synthesis were used.
\end{abstract}

Keywords: organization, new service, development, strategy, strategic decision, consumer

DOI: $10.7176 / \mathrm{EJBM} / 11-3-18$

\section{Introduction}

All companies that work in the service sector face a wide range of competitive challenges because of worldwide globalization. The rapid development of innovation promotes to look for technologically based solutions and the constantly changing consumer behavior leads to a search for new, more effective ways to meet their needs and maintain loyalty. In order to be distinguished in the market of services, business entities are forced to take their activities from a long-term perspective where the key point is to form a new strategy or to improve an already existing strategy. A properly prepared and consistently implemented strategy allows the business entity to achieve its business goals, assess its progress, allocate resources properly and understand all needs of the targeted customers. In this case, the development of new services can be compared with a strategic solution that can be a long-term business plan for many companies working in the sector of services. Development of new services can be associated with the usage of expertise and knowledge of a company in order to strengthen the position of a particular company in the service sector. Although the development of new services becomes increasingly important in the overall context of organizations as it has been analyzed fragmentary by researchers. It should be noted that the strategic approach to the added value of new services development for organizations is constantly changing, as a result, this research is relevant in the context of modern business organizations.

The object of the research - new service development as a part of organization strategy.

The novelty of the research - many studies related to the development of new services were focused on the origins, structure or roles of participants of this process, but in the context of constantly changing business conditions, it is necessary to determine the significance of this process for the future strategies of modern organizations.

The aim of the research - to determine the significance of new service development in the context of an organization strategy.

The following goals of the research were set: 1) to analyze the concept of the strategy and its significance; 2) to disclose the concept of service development; 3) to evaluate the significance of the development of a new service in terms of the organization strategy. The research is based on the methods of scientific literature analysis, synthesis and modelling.

\section{Methods of research}

The methods of comparative analysis and synthesis were used in the research. The research was conducted in four stages. The first stage can be described as a preparation for the scientific literature analysis. In order to assess the added value of new services development from a strategical point of view, the most relevant keywords that would provide a wider range of search results were selected. The following terms and expressions were used as keywords: importance of developing new services, significance of new service development, NSD as a part of organization strategy, NSD in the context of organization strategy, NSD importance, strategy, new service development value, service sector. The databases such as Emerald insight, Oxford university press, EBSCO, SAGE journals, Tailor \& Francis, Google Scholar, Science Direct, Springer Link, were analyzed as well as other data sources were used to search for the scientific literature. The selection range of scientific publications was restricted by the particular years of the publications. The second stage can be identified as a selection. During 
this stage, all publications found in the previous-mentioned databases were systematically sorted by specific criteria. The total number of found scientific publications was 41.9 of them were repetitive and other 20 publications did not meet the selection criteria. In the third stage, a comparative analysis was conducted. During this stage, 12 of finally selected publications were classified according to the attitude of different authors towards the significance of a new service development for a business strategy. All scientific methods chosen in this research are interrelat

ed and were used in the works of other researchers. As a result, it can be assumed that the decision to choose the previous-mentioned methods will ensure the reliability, validity and further dispersion of the final results.

\section{The concept of strategy}

The term "strategy" can be dated a long time in ancient Greek. From the military point of view, various strategies were formulated in a time of wars in order to occupy the larger territories and in time of truce in order to find the most effective negotiating plan. In the first half of the 20th century, the term "strategy" popped out in the literature of social sciences and the researches have started to talk about the importance of strategy for the management processes. Currently, the role of individual strategic tools for business is analyzing in different works. The scientific literature can provide evidence how a well-prepared and successfully implemented strategy can help to plan business plan more effectively and achieve the organizational goals easier.

According to K. Günther (2016), it is necessary to create a clear and reliable strategy in order to achieve economic success and ensure the proper performance of an organization. K. A. Bantel (1997) claims that certain strategies of particular products and markets are effective in achieving concrete goals and results of working. Meanwhile, O. M. Falsarella and C. A. S. C. Jannuzz (2017) quotes H. Mintzberg and J. B. Quinn (2001) and point out that a well-formulated strategy allows managing the resources when the internal competencies of employees are taking into account.

J. Neumann and O. Morgenstern (1947) define a strategy as an action that the company carries out in a particular situation. J. Kay (1993) agrees with the above-mentioned definition and adds that strategy is one unit of different actions which depends on the internal capacities of a company as well as the external relations and acquaintances. Also, the interaction withal concerned parties as employees, clients or shareholders are included. According to the author, the analytical methods are used in the development of strategy and these methods help an organization to understand what position in a market do they have. H. Ansoff and E. McDonell (1990) identify the strategy as a set of decision-making rules for managing the organization. According to the authors, there are four different types of rules: the standards for assessing the current and future performance of a company; the rules for developing relations with the external environment (product strategy and marketing, business strategy); the rules of organizational relations and internal processes managing (organizational concept); the rules that describe the business actions in a daily activities of a company (operational policy).

M. Porter (1996) made researches about the importance of the strategy for an organization. He points out that a strategy is the creation of a unique and valuable position which covers different fields of activities. According to the author, a properly prepared strategy has the following advantages: 1) it creates the possibilities to become an exceptional subject; 2) the strategy allows an organization to describe the direction of activity clearly, therefore it is easier to understand what should be done and what cannot be done; 3) a proper implementation of a strategy in company processes allows to coordinate and combine all activities; 4) the organization's strategy allows employees to follow the workflow and more understand the daily tasks and decisions.

According to C. Markides (1999), the key pint of strategy is to choose one position that a company can treat as its own. The strategic position is the sum of the answers to the following questions: 1) Which customers should targeted by a company? 2) What goods or services should be offered to the targeted customers? 3) How can company do it more effectively? According to the author, strategy basically is a choice, and a company will be successful only if the chosen strategy will be exclusive and differ from the competitors. Usually, the failure of the strategy is not a proper way of implementation of the three above-mentioned factors. V. Kvint (2009) emphasizes the aspect of success too and define a strategy as a system that allows an organization to find, formulate and develop a doctrine which can ensure long-term success. According to the author, a strategy must be implemented consistently in order to achieve the desired results.

After conducting a comparative analysis of different definitions of a strategy, S. Valentinavičius (2009) noted that all definitions have four common elements: the environment, its positive and negative aspects; the main operational objectives when the statement of the mission of an organization is the main point; the analysis of the situation; the plan how to use all available resources. According to the author, the strategy can be called a long-term plan of a development process of an organization and a system of operational activities for a defined period that enables an organization to achieve its goals and is based on all activities, forms, internal resources and external environment of an organization. P. Sadler (2003) distinguishes the aspect of a long-term plan of development. He claims that a strategy is a complex process of achieving long-term goals. P. L. Flemming 
(2014) notes that strategies should not be understood as any vision, mission, goals, priorities or plans of an organization. This is the direction chosen by executives in order to maximize the long-term added value which is created by an organization.

According to M. Išoraitè (2012), the success of a modern organization can only be guaranteed by a properly selected and implemented strategy of an organizational development. The author points out that any strategic change inevitably affects the people working in an organization and commit each of them to change as an individual. Changes do not only affect working and behavior of people but can change personal beliefs, viewpoint or attitude as well.

Analyzing the connection between strategy and values of organization Z. Monkevičienè and L. LiugailaitèRadzvickiene (2009) indicate that strategy usually is formed in order to achieve the goals or desired positions in a particular market. According to the authors, the strategy implies several important things: the decision-making process as well as the direction and orientation towards the future. An organization can choose many different ways to orientate its activities in a predictable direction.

After analyzing the concepts of strategy, it can be claimed that the definitions of strategy vary according to three main characteristics: the form of the expression of a strategy (action, a direction of business activities, system), its significance for the organization and the development period of a strategy (see Table 1).

Table 1 Generalized strategy definitions (Source: compiled by the author)

\begin{tabular}{|c|c|c|c|}
\hline Author, year & What is it? & Importance for organization & Period \\
\hline $\begin{array}{l}\text { J. Neumann, O. } \\
\text { Morgenstern } \\
(1947)\end{array}$ & Actions & - & - \\
\hline $\begin{array}{l}\text { H. Ansoff, E. } \\
\text { Mcdonell (1990) }\end{array}$ & $\begin{array}{l}\text { Set of rules } \\
\text { and actions }\end{array}$ & Helps to manage organizational processes & - \\
\hline J. Kay (1993) & Actions & - & - \\
\hline $\begin{array}{l}\text { M. E. Porter } \\
(1996)\end{array}$ & Position & $\begin{array}{l}\text { Allows to become exclusive; Allows to combine all } \\
\text { activities with each other; Allows employees to } \\
\text { understand everyday tasks more easily. }\end{array}$ & - \\
\hline $\begin{array}{l}\text { C. C. Markides } \\
\text { (1999) }\end{array}$ & Position & $\begin{array}{l}\text { Allows to discover targeted customers; Allows to } \\
\text { understand what goods or services the company } \\
\text { should offer; Lets understand how to do it more } \\
\text { effectively. }\end{array}$ & - \\
\hline P. Sadler (2003) & Process & - & Long-term goals \\
\hline V. Kvint (2009) & System & Helps in creating organizational doctrine & Long-term goals \\
\hline $\begin{array}{l}\text { S. Valentinavičius } \\
\text { (2009) }\end{array}$ & $\begin{array}{l}\text { Action } \\
\text { system }\end{array}$ & $\begin{array}{l}\text { Provides an opportunity for the organization to } \\
\text { achieve its goals }\end{array}$ & Long-term goals \\
\hline $\begin{array}{l}\text { Z. Monkevičienè, } \\
\text { L. Liugailaitè- } \\
\text { Radzvickienè } \\
\text { (2009) }\end{array}$ & Process & Indicates a direction for the future & Long-term goals \\
\hline M. Išoraitė (2012) & - & Encourages the exchange & - \\
\hline $\begin{array}{l}\text { P. L. Flemming } \\
\text { (2014) }\end{array}$ & $\begin{array}{l}\text { Direction of } \\
\text { activity }\end{array}$ & - & Long-term goals \\
\hline
\end{tabular}

When the review of scientific literature is done, it can be presumed that the concept of strategy is understandable in many different ways. There is no generic definition of strategy as a concept that would be approved by all researchers due to the constant improvement of the definition. Nevertheless, it is observed that many different definitions are characterized by the same features. Usually, a strategy is described as an action or a whole set of actions. Also, the long-term perspective is likely to be emphasized in definitions. Additionally, it is noted that some authors are tended to present specific questions while talking about the purpose and benefits of a strategy. When those questions are answered by the business entity, the answers can help to make the favourable conditions for implementation process of a strategy.

Considering the results of the analysis of the scientific literature, the strategy might be called a coherent set of coordinated actions that allow the business entity to use its key competencies and create a friendly environment to achieve the long-term goals. From the point of view of the development of new services, in order to implement an effective strategy, a business entity should answer the following questions: 1) What product or service should we offer? 2) What options we have for the product development? 3) Who is our targeted customer? 4) Is it compatible with the general strategy of the company? 5) Should we start doing this?

\section{Theoretical new service development aspects}

In the context of globalization, the precise definition of the term of a new service becomes one of the most 
complex theoretical tasks for modern researchers. In scientific literature, this term acquires a broader meaning: new service creation (NSC), value/service co-creation, new service development (NSD) or even service design. In order to more accurately evaluate the process of developing new services, it is necessary to carry out their analysis (see Table 2).

Table 2. Comparative analysis of the concepts of development of new services (Source: compiled by the author)

\begin{tabular}{|c|c|c|}
\hline Author & Year & New service development \\
\hline B. Edvardsson, J. Olsson & 1996 & $\begin{array}{l}\text { The main task of service development is to create the right generic } \\
\text { prerequisites for the service. This means an efficient customer process: } \\
\text { the process must be adapted to the logic of the customer's behaviour and } \\
\text { a good customer outcome, that is, the service is associated, in the eyes of } \\
\text { the customer, with quality and added value. }\end{array}$ \\
\hline E. Stevens, S. Dimitriadis & 2005 & $\begin{array}{l}\text { Major competitive factor for the service industry (Johnson et al., 2000; } \\
\text { Fitzsimmons and Fitzsimmons, 2001). }\end{array}$ \\
\hline M. Erlhoff, T. Marshall & 2008 & $\begin{array}{l}\text { This process is intended to create a service that is in the best interest of } \\
\text { the client and the business entity that provides it. }\end{array}$ \\
\hline $\begin{array}{l}\text { D. Kindström, C. } \\
\text { Kowalkowski }\end{array}$ & 2009 & $\begin{array}{l}\text { The process of new service development is generally complex and can be } \\
\text { problematic to define and articulate and there are a number of unique } \\
\text { aspects of service development that need to be taken into account that do } \\
\text { not necessarily exist in manufacturing companies new product } \\
\text { development processes. }\end{array}$ \\
\hline S. Moritz & 2010 & $\begin{array}{l}\text { Process focused on the creation of the added value for both players of the } \\
\text { market. }\end{array}$ \\
\hline J. C. Aurich et al. & 2010 & $\begin{array}{l}\text { Process of planning the components of human recourses, technologies } \\
\text { and materials, in order to improve the quality of interaction between } \\
\text { customers and service providers. }\end{array}$ \\
\hline C. Riedl et al. & 2010 & $\begin{array}{l}\text { Development of new services is a effective method that describes the } \\
\text { main processes and tasks. }\end{array}$ \\
\hline $\begin{array}{l}\text { J. B. Santos and M. } \\
\text { Spring }\end{array}$ & 2013 & $\begin{array}{l}\text { Activities executed and decisions made to develop the concept, analyse } \\
\text { the opportunity, implement and launch the service }\end{array}$ \\
\hline $\begin{array}{l}\text { F. M. Quaggio, M. T. } \\
\text { Silva }\end{array}$ & 2015 & $\begin{array}{l}\text { Complex process constituted by a serie of activities, tasks and } \\
\text { information flow necessary to a company to create a concept, develop, } \\
\text { evaluate and implement intangible new products, valuable to their clients. }\end{array}$ \\
\hline $\begin{array}{l}\text { Cambridge Service } \\
\text { Alliance }\end{array}$ & 2017 & $\begin{array}{l}\text { The application of technologies, methodologies and tools to the } \\
\text { development of new service offerings and the improvement of service } \\
\text { systems. }\end{array}$ \\
\hline $\begin{array}{l}\text { I. Skačkauskienè, A. } \\
\text { Radzevičienè, P. } \\
\text { Švogžlys }\end{array}$ & 2017 & $\begin{array}{l}\text { Multiple, customer-oriented process, during which managerial decisions } \\
\text { are applied to the elimination of deficiencies in business, by improving } \\
\text { existing ones or by introducing new services. }\end{array}$ \\
\hline
\end{tabular}

The results of the comparative analysis revealed that the theoretical field of the concept of new services development is quite broad. It is a multidisciplinary and ongoing process. Although there are many different variations of this term in the scientific literature. However, there are few the same features and they might be classified into four groups: 1) the relationship between an organization and customers; 2) the importance of the objective; 3 ) the specific execution of the process in stages or its progress; 4) the significance of this process for an organization. All these features reveal that the development of new services can be oriented towards the implementation of new services or the improvement of already existing services. All factors such as consumer behaviour or technological innovations encourage a business entity to reach rational and competitive decisions that will help the process of new services development to be done in a more effective way. As a result, many researchers define the development of new services as a competitive advantage, so it can be assumed that this process is a strategic decision and a consistent implementation of it becomes an essential part of an overall strategy of an organization.

\section{The importance of developing new services in terms of organization strategy}

The majority of modern business entities take the influence of external and internal factors into account while a strategy or a long-term plan of actions is creating. Usually, the competitors, suppliers, targeted customers, other opportunities and threats that affect the business are described as the external factors. The internal factors are the attitude of employees toward the developed strategy, the possibility of adopting technological innovations in a market or the targeted orientation of a strategy (see Fig. 1). According to S. Valentinavičius (2009), the choice of the strategy can be determined by the external possibilities (threats) or internal strengths (weaknesses) of the 
business entity, which can be revealed after the strategic analysis. The strategic decision is selected from a set of alternatives according to the targeted orientation of the strategy and other criteria of evaluation.

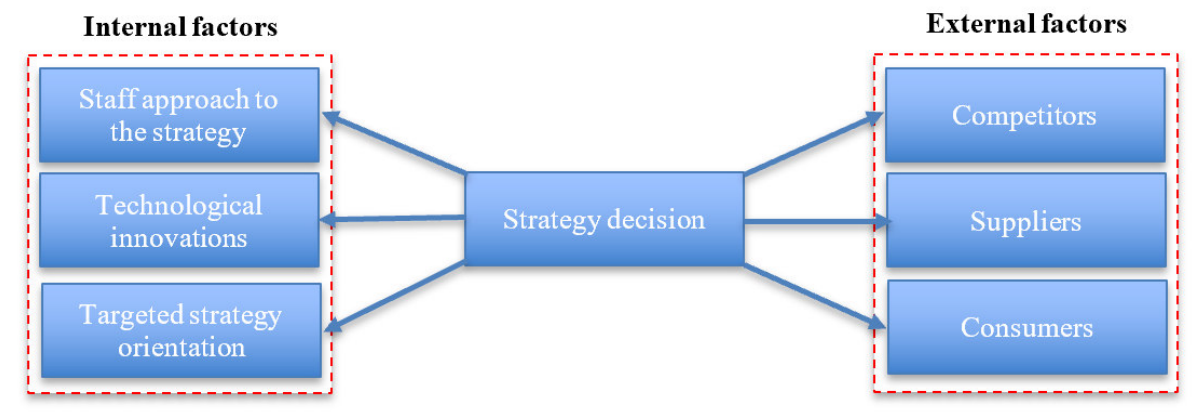

Figure 1. The principal scheme of strategic decision context (Source: compiled by the author)

Figure 1 shows that the identification of internal and external factors is an excellent tool for formulating the frame of the future business strategy. However, what if the purposeful implementation of the strategy depends on the business activities and the sector in which the business entity is operating? In this case, the business entity that operates in the context of services must figure out the importance of developing new services for the formation of a general strategy or the further implementation of this strategy.

J. P. J. Jong and P. A. M. Vermeulen (2003) state that the newly developed service should fit the overall strategy of a company. This could ensure that the new service is adjusted to the target market and it matches the available resources of a company: people, knowledge or investment. According to the authors, these are important aspects for the successful future of a company. The organizational resources are highlighted by C. M. Froehle and A. V. Roth (2007) too. They state that service providers who have the innovation-based strategies are more likely to facilitate the development of a new service, are able to use their resources efficiently, and can work in a competitive business environment. According to the authors, the technological, procedural and design choices are strategically important to the company abilities to quickly and effectively develop a new service. B. Edvardsson et al. (2005) talk about the competitive abilities of the services and overall organization strategy. He points out that a newly developed service is one of the ways to differentiate that new service in a market and create a unique value of a new service for customers. According to Weerawardena and J. R. McColl-Kennedy (2002), the main advantage of developing a new service is to strengthen the competitive advantages of a company. According to the authors, those advantages may be based on the incapacity of competitors to duplicate the unique features of a new service. According to A. Awwad and D. M. Akroush (2016), the development of new services helps a company to grow in a particular market and successfully compete in a modern business environment. A similar point of view is expressed by N. Bhuiyan (2011). He states that the development of new products is a crucial point to ensure the continuity of a business. S. O. E. Ewah et al. (2008) claims that the development of new products is simply vital to the success of a company in a constantly changing business environment. It helps to increase the loyalty of consumer, create a more attractive portrait of a company and promote the consistent adoption of innovations in developing services. According to Bullinger et al. (2003), the main challenge faced by companies is a constant need to offer new services for the same market. In this way, it is expected to surpass the competitors and satisfy more needs of customers. B. Edvardsson and J. Olsson (1996) claim that the development of a new service allows a company to stand out in a competitive environment and improves the quality of the internal processes of the company. Y. Wang and L. Yang (2015) highlight the importance of the overall image of a company. The authors reveal that a sudden interest in a new service might create a stronger relationship with the consumer. M. Sajid et al. (2015) states that the effective development of new products remains an important business activity because large and small companies are still struggling to gain or maintain a competitive advantage. According to the authors, this tool helps to ensure the effective implementation of projects and the successful operation of a company as well. D. Owens (2006) states that the development of new products can open the new markets, shorten the life cycle of a product, promote technological development and improve the satisfaction of consumer needs.

The authors highlight many advantages of the process of new services development in terms of the overall organization strategy (see Table 3). 
Table 3. From the strategic point of view, the factors that define the importance of new service development (Source: compiled by the author)

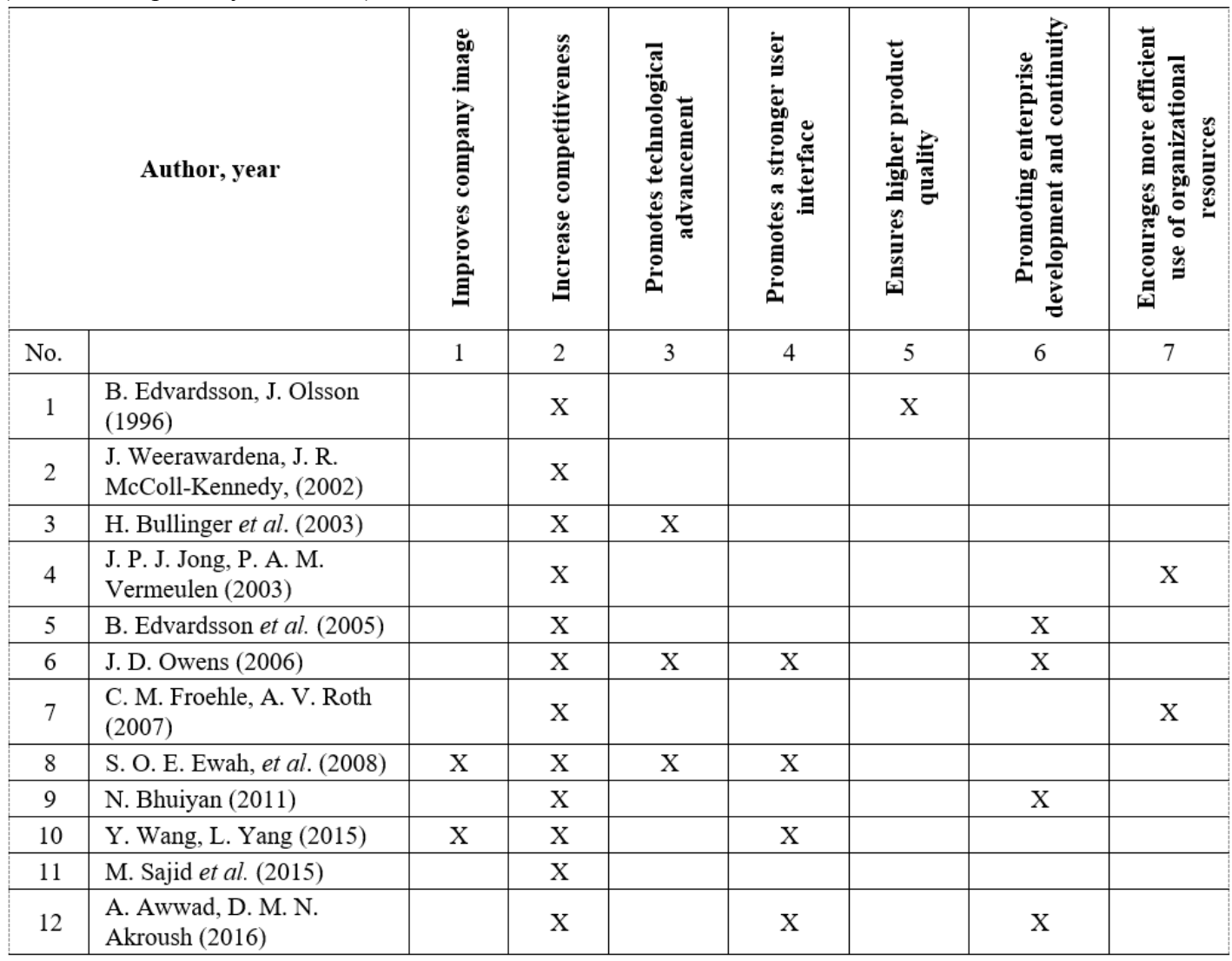

It has been noted that when talking about the development of new services, many authors are tending to call this process a competition and distinguish its advantages. This suggests that the development of new services is not only a process for developing or improving a particular service, but it also becomes a rational strategic tool that allows the company to differentiate their service in a market, distinguish themselves from the competitors and attract the potential consumer.

\section{Conclusion}

After analysing the terms of the strategy presented by different authors, it has been noticed that the definitions vary according to the three main indications: the form of the strategy expression, the significance of strategy for the business entity or the development period of the strategy.

The majority of authors describe the strategy as a long-term direction of the business activities set by the business entity in order to achieve a competitive advantage in a market. It allows making a presumption that usually the strategy is developed for a longer period than the business plans.

The results of the analysis revealed that the well-prepared strategy and proper implementation of it can have a positive benefit to the further business results. Among the commonly mentioned advantages, the authors identify the opportunities for the optimal working processes optimization, efficient planning, faster response to market changes and the ability to better understand the core values and competencies of the business entity.

In this article, a theoretical study has been carried out, so in the future in the overall context of the organization strategy, there is enough space for quantitative research. This would lead to results that would further represent the value of new service development in achieving the company's long-term or short-term goals.

\section{References}

Ansoff, H., Mcdonnell, E. (1990), “Implanting strategic management”, New Jersey: Prentice-Hall.

Aurich, C. J., Mannweiler, C. and Schweitzer, E. (2010), "How to design and offer services successfully", CIRP Journal of Manufacturing Science and Technology 2(2010), 136-143.

Awwad, A., Akroush, D. M. N. (2016), "New product development performance success measures: an exploratory research", EuroMed Journal of Business, 11(1), 2-29. 
Bantel, K. A. (1997), "Performance in Adolescent, Technology-Based Firms: Product Strategy, Implementation, and Synergy", The Journal of High Technology Management Research 8, 243-262.

Bhuiyan, N. (2011), “A framework for successful new product development”, Journal of Industrial Engineering and Management 4(4), 746-770.

Bullinger, H., Fahnrich, K., Meiren, T. (2003), “Service Engineering - Methodical Development of New Service Products", International Journal of Production Economics 11, 275-287.

Cambridge Service Alliance. (2017), "Service engineering definition", Available from Internet: https://cambridgeservicealliance.eng.cam.ac.uk/Research/Glossary

Edvardsson, B., Olsson, J. (1996), "Key koncepts for new service development”, The service industries journal 16(2), 140-164.

Edvardsson, B., Gustafsson, A., Enquist, B. (2005), "Challenges in New Service Development and Value Creation through Service”, ISD’2005 conference, 14-17 August 2005, Karlstad University Sweden.

Erlhoff, M., Marshall, T. (2008), "Design Dictionary”, Basel: Springer Basel AG.

Ewah, S. O. E., Ekeng, A. B., and Umanta, U. E (2008), "Synthesis of new product development success", Global Journal of social sciences, 7(2), 115-120.

Falsarella, O. M., Jannuzz, C. A. S. C. (2017), “Corporate Strategic Planning and Information \& Communication Technology Planning: a project based approach”, Gestão \& Produção, 24(3), 610-621.

Fitzsimmons, J. A., Fitzsimmons, M. J. (2001), "Service Management, Operation, Strategy and Information Technology", 3rd ed., McGraw-Hill, New York, NY.

Flemming, P. L. (2014), “A Review of Strategic Planning Models Developed Over the Past 50 Years, and Their Effectiveness in Public Sector Organizations", Proceedings of International Conference on Leadership, Management and Strategic Development.

Froehle, C. M., Roth, A. V. (2007), “A Resource-Process Framework of New Service Development”, Production and Operation Management, 16(2), 169-188.

Günther, K. (2016), “Key Factors for Successful Implementation of a Sustainability Strategy”, Journal of Applied Leadership and Management, 1-20.

Išoraite, M. (2012), “Teoriniai strateginių pokyčių aspektai”, Business Systems and Economics 2(2), 69-82.

Johnson, S. P., Menor, L. J., Roth, A.V., Chase, R. B., (2000), "A critical evaluation of the new service development process: integrating service innovation and service design”, In: Fitzsimmons, J.A., Fitzsimmons, M.J. (Eds.), New Service Development-Creating Memorable Experiences. Sage Publications, Thousand Oaks.

Jong, J. P. J., Vermeulen, P. A. M. (2003), “Organizing Successful New Service Development: A Literature Review”, Retrieved from https://core.ac.uk/download/pdf/7074545.pdf

Kay, J. (1993), "Foundations of Corporate Success". Oxford University Press.

Kindström, D.; Kowalkowskic, C. (2009), "Development of industrial service offerings: a process framework", Journal of service management 20(2), 156-172.

Kvint, V. (2009), “The Global Emerging Market: Strategic Management and Economics”, Routeledge

Markides. C. C. (1999), “A dynamic view of strategy”, Retrieved from https://sloanreview.mit.edu/article/adynamic-view-of-strategy/

Mintzberg, H., Quinn, J. B. (2001), "O processo da estratégia”, (3 ed.). Porto Alegre: The Bookman.

Moritz, S. (2010), "Service Design: practical access to an evolving field", Revised http://www.servicedesignbooks.org/isbn/9781445206677/service-design/

Monkevičienè, Z. Liugailaitè-Radzvickienè, L. (2009), "Organizacijos Strategijos ir Vertybių Sąsaja", Economics and Management 14, 315-322.

Neumann, J., Morgenstein, O. (1947), “Theory of Games and Economic Behavior”, 2nd ed. Princeton: Princeton University Press.

Owens, D. J. (2006). "Why do some UK SMEs still find the implementation of a new product development process problematic? An exploratory investigation”, Management Decision Journal 45(2): 235-51.

Porter, M. E. (1996), "What is strategy?" Harvard Business Review 74: 61-78.

Riedl, C.; Leimeister, J. M.; Krcmar, H. (2010), "Why e-Service Development is Different: A Literature Review", e-Service Journal 8(1): 1-37.

Sadler, P. (2003), "Strategic management" 2nd edition. Londýn: Kogan Page Limited.

Sajid, M., Al-bloush, B. H., AL-Faieq, M., Monsef, S., Sadeghi, M. (2015), "Role of innovation in the development of new products for improving organizational performance", Journal of Advanced Management Science, 3(3): 261-264.

Santos, B. J.; Martin, S. (2013), "New service development: managing the dynamic between services and operations resources", International Journal of operations and production management 33(7): 800-827.

Skačkauskienè, I., Radzevičienè, A., Švogžlys, P. (2017), "Conceptual new service development model”. 10th International Scientific Conference Business and Management 2018, May 3-4, 2018, Vilnius, Lithuania 
Section: Contemporary Business Management Challenges and Opportunities.

Stevens, E., Dimitriadis, S. (2005), "Managing the new service development process: towards a systemic model", European Journal of Marketing 39(1/2), 175-198.

Quaggio, F. M., Silva, M. T. (2015), "Professional Services Redesign: a Challenge to New Service Development Models", Brazilian Journal of Operations \& Production Management 12(2015), 40-47.

Valentinavičius, S. (2009), "Verslo strategijos formavimo ìmoneje teoriniai aspektai”, Business: Theory and Practice 10(2), 130-141.

Wang, Y., Yang, L. (2015), "Business Social Responsibility to Improve New Product Development”,Journal of Economics, Business and Management 3(5), 510-513.

Weerawardena, J., McColl-Kennedy, J. R. (2002), "New service development and competitive advantage: A conceptual model", Australasian Marketing Journal 10(1), 13-23. 